\title{
Bribes, Rents and Industrial Firm Performance in Albania and Kosovo
}

\begin{abstract}
Using data from a novel representative survey, we examine how corruption affects the performance of industrialsector firms in Albania and Kosovo, two low-middle income post-socialist economies in the Western Balkan region. Bribes are costs that firms incur to "grease the wheels" of the bureaucracy and/or to seek rents. Rents, however, may improve firm performance. Thus, to estimate the total effect of corruption, we develop and collect a set of perception-based indicators of both corruption and rents. In addition, we allow both bribery and rents to affect output growth through multiple channels - by influencing the firm's investment and hiring decisions, by affecting total-factor productivity and by modifying the marginal product of factor additions. We find that, in Albania and Kosovo, bribes and rents have both positive and negative effects on firm performance. The net effect of corruption, however, is negative and large, and is not fully offset by the beneficial effects of rents.
\end{abstract}

KEYWORDS

Corruption, Rents, Rent-Seeking, Industrial Policy, Transition, Western Balkans

\section{Introduction}

With the early stage of marketisation reforms almost completely over, the post-socialist countries have embarked on ambitious efforts to build and consolidate market-supporting institutions (Douarin and Mickiewicz 2017). In this context, corruption - the sale by public officials of government property for personal gain - has climbed to the very top of the "transition agenda". Donor agencies have financed anti-corruption programmes all across the transition region. Meanwhile, corruption reduction has become a key element of EU conditionality in the Western Balkans, where six post-socialist economies (the "Western Balkans-6", or WB-6) are hoping to join the European Union in the not-too-distant future. In Albania, for instance, corruption is "regarded as the country's main problem, overshadowing [....] unemployment, crime and low wages" (UNDP 2016, p. 6).

Because of a strong focus on institution-building and anti-corruption, the WB-6 have attached relatively little important to promoting industrial development (Bartlett 2008). More recently, however, the donor community has woken up to the risks inherent in a growth model based primarily on aid- and remittance-driven consumption, calling on the WB-6 to launch new measures to strengthen and diversify their productive base (Lemay-Hebert and Murshed 2016; World Bank 2017). Industrialisation has long been regarded as an important engine of economic growth and social change (Szirmai 2012, Szirmai and Verspagen 2015). A long-standing literature has also emphasised the critical role of the state in promoting industrial development (Khan, 
2000; Chang, 2002). Yet, a popular and oft-cited criticism of industrial policy is that it breeds corruption and rent-seeking (Ades and Di Tella, 1997).Thus, for the WB-6, an important policy question is how corruption relates to industrial policy in the context of firm development. Do industrial policy rents bring benefits to recipient firms? Are rent transfers associated with corruption? If so, how costly is that corruption? Do the costs of corruption offset the benefits, if any, of the rent transfers that firms secure by means of bribery?

To answer these questions, we examine new perception-based indicators of corruption and rents from a representative survey of 239 mining and manufacturing firms conducted by the authors in Albania and Kosovo, the two poorest WB-6 economies. These two countries are very similar in many important respects - level of development, language and culture ${ }^{1}$, historical (socialist and Ottoman) legacies, institutional endowments, policy environment and market openness. It is therefore appropriate to examine them together. Our purpose is to draw conclusions about the population of industrial firms in Albania and Kosovo, although our findings are likely to be relevant for the WB-6 economies more generally, as well as other low-middle income transition countries.

The micro literature highlights a number of mechanisms through which corruption may influence firm performance. ${ }^{2}$ The process of negotiating corrupt transactions diverts management time from the task of supervising and coordinating production, leading to shirking and lower productivity. Corruption may also induce a misallocation of inputs, as firms might have to employ additional labour to make up for the productivity loss caused by corruption. To cope with corrupt officials, bribe-paying firms may also have to increase the ratio of administrative to technical/engineering staff. The need to maintain secrecy, moreover, may promote the adoption of management strategies that hamper innovation, further reducing productivity. ${ }^{3}$ Since corrupt transactions are illegal and cannot be enforced in the courts, the uncertainty caused by a "corrupt" business environment may have a chilling effect on the firm's investment and hiring decisions. Lastly, the bribes themselves are real monetary costs which reduce profits and diminish the pool of resources available for re-investment.

A fast-growing literature presents evidence consistent with these mechanisms. Based on panel data from Latin America, Dal Bo and Rossi (2007) find a large negative effect of countrylevel corruption perceptions on the labour productivity of electricity distribution firms. Fisman and Svensson (2007) use a sample of Ugandan firms to show that an increase in the share of total

\footnotetext{
${ }^{1}$ Around 90 percent of the population of Kosovo is ethnic-Albanian.

${ }^{2}$ See references in the next paragraph.

${ }^{3}$ These include concealing accounting information or limiting employee participation in firm decision-making.
} 
revenues paid in bribes has a detrimental effect on the rate of sales growth. Focusing on Latin America, Seker and Yang (2014) examine the consequences of firms' exposure to bribe solicitations and find a robust negative effect of corruption on firm sales. Based on a crosssection of firms from 10 transition economies, Athanasouli and Goujard (2015) uncover a negative relationship between regional-level corruption and a firm-level measure of management quality. The only partial outlier in this literature is the paper by Commander and Svejnar (2011), which reports a mostly insignificant effect of corruption on total-factor productivity (TFP) in 26 transition economies.

While most economists agree that corruption has an unambiguously deleterious impact on firm performance, two parallel literatures have called for caution and nuance. The classic "grease the wheels" hypothesis contends that bribes can work as "speed money", allowing firms to side-step cumbersome regulations or speed up the delivery of essential government services (Leff 1964; Lui 1985; Meon and Weill 2010; Heckelman and Powell, 2010). ${ }^{4}$ In developing and transition countries, firms are often subject to extortion by public officials, who demand sidepayments to perform tasks (e.g. provide a water connection) or issue documents (e.g. health and safety certificates) that they would have an obligation to perform/issue to all eligible businesses as a matter of course. In these contexts, bribes are costs that firms must incur in order to "get things done". Holding constant the presence of extortion by public officials, the firms that refuse to pay are at a competitive disadvantage.

In other cases, firms pay bribes not to "grease the wheels" of a mechanism that should in principle work without "grease", but to seek special privileges - that is, rents. Recent contributions have moved the conversation from the bribe payments to the special privileges the investment licenses, public contracts, subsidies and monopolies - that some firms capture by means of bribery (Khan 2001; North et al. 2012; Uberti 2016). The bribes are by definition costs (and, as discussed above, by far not the only costs of corruption); the rents, however, may improve firm performance. Thus, the net effect of corruption depends on both the magnitude of the rent-seeking cost and the value of the rents created and distributed as a result of rentseeking (Khan 2000). While the rent-seeking "input" is always negative, the "outcome" of the rent-seeking process may be positive if the rights and rents allocated promote accumulation and learning. To date, the empirical literature has focused almost exclusively on the "bribe side" of corrupt transactions. Although the efficiency and output loss occasioned by rent-seeking are well

\footnotetext{
${ }^{4}$ Here, I do not discuss the macro literature on corruption and growth at the country level. See Aidt (2009) for a review.
} 
documented, the potentially beneficial effects of corruption on the "rent side" have received considerably less attention.

To examine how bribes and policy rents affect firm performance in Albania and Kosovo, we extend traditional approaches along three main lines. First, we allow corruption to influence systematically all aspects of the production process. Whereas most existing contributions estimate the total impact of corruption on firm sales ${ }^{5}$, we disaggregate its total effect on output into two main components: a "direct" effect through total factor productivity (TFP) - the efficiency with which factor inputs are combined - and an "indirect" effect through the rate of factor (especially, capital) accumulation. Whether bribes are paid to "grease the wheels" or to seek rents, "corrupt" firms internalise a cost - a cost that is not incurred by firms that do not engage in corruption. It is unclear, however, whether this cost comes primarily in the form of a productivity or investment loss.

Second, we explicitly test for a "greasing" effect of corruption at the firm level. We do so by allowing for potential complementarities between corruption, investment and hiring decisions. The intuition here is that fixed-capital investments may not translate into additional sales revenue unless the firm can resolve the logistical and bureaucratic bottlenecks associated with operating the new equipment. Corruption helps managers get past these hurdles. Thus, although "corrupt" firms may incur a cost in the form of a TFP or investment loss, the corruption may enable them to "grease the wheels" of the system and thereby reap higher returns from an additional unit of capital. To our best knowledge, this is the first paper that explicitly includes an interaction term between factor inputs (capital and labour) and corruption, allowing for the marginal product of factor additions to depend on the incidence of corruption.

Third, we use our survey data to construct four perception-based indicators of rent allocations in the firm's business environment. In line with the assumption that rents are often allocated corruptively, the overwhelming majority of the firms that claim to receive rents in our sample also report high levels of corruption in their immediate environment. As with corruption, we examine the impact of rents on several aspects of the production process, allowing for the firms that extract rents to experience higher (or lower) levels of performance compared to firms, "corrupt" or else, that do not succeed in extracting rents.

Lastly, this paper contributes to the micro literature on corruption by focusing specifically on the effects of corruption on industrial-sector firms, rather than firms in general. To our best

\footnotetext{
${ }^{5}$ With the exception of Command and Svejnar (2011).
} 
knowledge, this is the first paper with this particular focus, at least in the context of the transition literature.

Our findings suggest that, in the two poorest Balkan economies, the costs of corruption manifest themselves in the form of a large TFP loss. Corruption, however, is not associated with changes in the firm's investment and hiring decisions. In line with the "grease the wheels" hypothesis, we find robust evidence that corruption and capacity expansion are complements: the marginal product of capital and labour is non-zero only if the firm is "corrupt". That said, the returns from corruption - its "greasing" effect - are dwarfed by the costs of corruption - its negative impact on TFP. Next, we find that, holding corruption constant, rent allocations are correlated with higher rates of TFP growth. The effect of rents on capital and labour accumulation, however, is more mixed and depends on the type of rent. Overall, the benefits earned by the winners of rent-seeking contests - that is, the firms that succeed in capturing special privileges, typically by corrupt means - are again dwarfed by the costs incurred in the process of rent-seeking. Although it is always difficult to firmly establish causality when working with perception-based indicators, throughout our analysis we pay particular attention to mitigating the risk of omitted variable bias.

The rest of the paper is organised as follows. In the next section, we provide some background on the recent transformation of industry in Albania and Kosovo. Based on qualitative fieldwork research, we discuss the most common types of rents and rent-seeking in these two economies, and how they affect industrial-sector firms. The purpose is to formulate contextsensitive hypotheses that may be tested econometrically. Section 3 presents the data and the enterprise survey. Section 4 examines empirically the impact of rents and bribes on TFP growth, while section 5 discusses their influences on factor accumulation.

\section{Background and Testable Hypotheses}

\subsection{Post-socialist Industrial Transformation}

In Albania, the fall of the communist regime in late 1990 precipitated a rapid and tumultuous transition to market democracy. In Kosovo, by contrast, the transition process did not begin in earnest until the end of the 1999 conflict. Following a relatively short period of economic contraction, Albania's industrial sector witnessed a quick recovery during 1998-2007. By 2007, the average annual growth rate of industrial output had levelled off at around 4 percent. ${ }^{6}$ In

\footnotetext{
${ }^{6}$ This account is largely based on Uberti (2017).
} 
Kosovo, value-added growth in industry averaged 6.8 percent during 2007-15. In both countries, industrial growth was still substantially lower than in more dynamic transition economies such as China (9.9 percent). Within industry, manufacturing has performed relatively worse - with growth rates averaging 6.4 percent in Kosovo and 2.8 in Albania (2007-15) - confirming the enduring role of primary-commodity industries, especially in oil- and mineral-rich Albania. In both countries, industrial development is largely driven by factor mobilisation rather than productivity improvements. In Albania, the rate of labour productivity growth in industry was effectively zero during 2005-14, while in Kosovo it averaged 5 percent during 2013-15.

As in many other post-socialist economies, the transition process was accompanied by substantial de-industrialisation. ${ }^{7}$ In contrast to other post-socialist economies, however, the contraction (in Kosovo) or collapse (in Albania) of the old state sector has not paved the way for the discovery and development of new comparative advantages in higher-return sectors. Rather, both Albania and Kosovo have re-inserted themselves in the global economy as exporters of primary commodities and labour-intensive goods. In Albania, oil, mining and metals account for nearly 60 percent of total industrial value-added (in 2013) and generate an increasingly large share of total export earnings (24 percent in 2016, up from less than 10 percent before 2004). An outward-oriented apparel and footwear industry emerged and expanded rapidly in the early transition years, spawning multiple clusters of maquiladora-type establishments performing simple cut-make-and-trim operations. This sector is the largest employer in industry and accounts for the largest export share. Performance in more skill- and technology-intensive industries has lagged far behind, and there is virtually no production of capital goods and consumer durables.

In Kosovo, the industrial structure is generally more inward-looking than in Albania. Most capital-intensive operations are confined to a small number of foreign-owned, export-oriented "enclaves" (Uberti 2014). Almost half of total export revenues are dominated by a single (foreign-owned) nickel-smelting plant located in Drenas/Glogovac. An inward-looking food and beverage industry, which accounted for over 50 percent of total industrial value-added in 2013, is flanked by other labour-intensive, import-substituting sectors (plastics and rubber, metals processing) performing simple finishing, packaging or tailoring tasks (Uberti 2019, p. 316). In contrast to Albania's, the overwhelming majority of Kosovo's exporting firms (including the nickel smelter) are former socially-owned enterprises (SOEs).

\footnotetext{
${ }^{7}$ In 2014, industry accounted for less than 10 percent of GDP in Albania and manufacturing for just over 10 percent in Kosovo.
} 


\subsection{Corruption}

According to informal accounts and the own perceptions of firm managers, corruption remains an important constraint on industrial restructuring and development (UNDP 2012). In Kosovo, it is a common practice to award public-sector jobs to political supporters (Capussela 2015, p. 195). Job patronage sets off a vicious circle in which the high front-loaded cost of building political connections and/or "buying" public-sector jobs creates incentives for office-holders to solicit bribes in a bid to recoup their initial "investment". As a result, "corruption is widespread from the supreme court all the way down to the lower levels of the municipalities". ${ }^{8}$ Similarly, state jobs in Albania's public administration and in state-owned enterprises (e.g. the grossly overstaffed national oil company) are traditionally awarded to party clients, with electoral rotations triggering waves of personnel turn-over. Suggestively, the manager of a mining firm remarked that "corruption is a chain that extends from the base [of the state apparatus] all the way up to top-level political figures". ${ }^{9}$

Of course, the frequency of contact with the state varies across firms, as does the prevalence of corruption across different public agencies and the individual firm's idiosyncratic propensity to pay bribes, if bribes are indeed solicited. These factors are therefore likely to generate variation in firm-level experiences of corruption.

Making contact with the official to whom the bribe must be paid, negotiating the bribe and concluding the transaction is a risky and time-consuming task, which requires personal connections, social capital, and local cultural knowledge. To (develop the capacity to) deal with corrupt officials, firm managers must divert time and effort away from managerial tasks (Dal Bo and Rossi 2007). For this reason, we expect total-factor productivity to be lower in firms that are more exposed to corruption (H1).

At the same time, bribe-paying firms incur a monetary cost that drains financial resources away from productive investment. These costs are not insubstantial. According to a chromium miner active in Bulqizë (Albania), the bribe that must be paid to high-level Ministry officials to obtain a mining license is in the order of two to three thousand euros. ${ }^{10} \mathrm{In}$ order to secure government contracts, firms in Kosovo report that they typically pay 9 percent of the contract value in bribes (World Bank 2010, p. 20). Thus, we expect firms that are more exposed to

\footnotetext{
${ }^{8}$ Interview No. 22 with firm manager from the metal-processing sector, March 2015, Ferizaj/Uroševac, Kosovo.

${ }^{9}$ Interview No. 41 with firm owner from the mining sector, July 2015, Tirana, Albania.

${ }^{10}$ Interview AL10 with firm owner from mining company, July 2016, Tirana, Albania.
} 
corruption to have lower retained earnings available for re-investment. Such firms will thus grow their capital-equipment stock at a lower rate $(\mathrm{H} 2) .{ }^{11}$

Nevertheless, the ability to access government services may be a necessary condition for firms to operate the capital equipment that is actually installed install. For instance, the owner of a Kosovar metal-processing company that requires round-the-clock electricity supply reports having to lobby the Ministry of Trade and Industry (and potentially pay bribes) when the newly privatised electricity distribution company, in a bid to cut costs, decided to cancel the night shift at the $10 \mathrm{kV}$ sub-stations across Kosovo, exposing all energy-intensive plants to the risk of downtime in the event of malfunctions. ${ }^{12}$ Another example is that of a foreign-owned cement factory prospecting for limestone in the Klinë/Klina region of Kosovo. After completing their exploration plan, the firm reported having problems obtaining the municipality's right of way -a legal requirement to convert an exploration license into a fully-fledged mining permit. The manager of the firm alleged that the local mayor was tactically delaying the issuing of the document in an attempt to solicit a bribe. These cases suggest that there may be a systematic complementarity between corruption and capacity expansion - the hiring of additional units of labour and capital. We thus expect the marginal product of labour and capital to be higher for bribe-paying firms (H3).

\subsection{Industrial Policy Rents}

So far, we have considered cases of corruption initiated by bureaucrats and politicians - that is, extortion. By contrast, when bribe payments are initiated by firms, as in the classic model of rent-seeking, the winners of rent-seeking contests enjoy various forms of preferential treatment - that is, rents. Following 2-3 decades of extensive liberalisation reforms, the range of industrial policy rents formally provided by the Albanian and Kosovar states is very limited. ${ }^{13}$ Nevertheless, rents may still be created and allocated informally. Previous contributions have used the term "covert" or "unwitting" industrial policy to describe such cases (Uberti 2014). Based on fieldwork research, we identified four types of rents that politicians provide to bribe-paying (or otherwise politically connected) firms: import protection; access to technical assistance programmes; grants, loans and subsidies; and political protection from "unfair" (informal-sector) competition. Let us review each of these in turn.

\footnotetext{
${ }^{11}$ We remain agnostic about the effect of corruption on employment growth.

${ }^{12}$ Interview No. 40 with firm manager from the metal-processing industry, March 2015, Viti/Vitina, Kosovo.

${ }^{13}$ As noted by the manager of a USAID project in Kosovo, "when talking about corruption, you need to ask about the benefits. In Kosovo, the list of [formal] benefits [that the state can provide] is very short" (interview 010 with representative of donor agency, March 2015, Pristina, Kosovo).
} 
Despite a formally liberal trade policy ${ }^{14}$, non-tariff barriers to trade - e.g. sanitary and phytosanitary standards, technical requirements on labelling and packaging - are extensively used in Kosovo and, especially, Albania as part of an informal strategy to control inward trade (MTI 2015, p. 51-54). Going beyond the stated goal of promoting food safety and disease control, these policy tools are often used tactically to grant targeted protection to domestic producers. In October 2014, for instance, Albania banned flour imports from regional partners citing new EUmandated quality standards. A similar row erupted in Kosovo in 2014 over the quality of Serbian flour, paving the way for an import ban. Allegedly, the scandals were fabricated politically to favour the only flour milling plant in Kosovo. ${ }^{15}$ The facility, located in the Western town of Xërxë/Zrze, had recently been privatised by a fast-growing conglomerate controlled by a family that is known to have tight personal connections with the then-ruling Democratic Party of Kosovo (PDK). Similarly, the temporary 35 percent customs duty imposed on cement imports in 2012 was reportedly intended to favour Kosovo's only cement factory, a foreign-owned former SOE based in Han i Elezit/Djeneral Janković (Capussela 2015, p. 197). ${ }^{16}$

Despite the lack of a comprehensive industrial policy strategy, a limited number of donor programmes have provided direct technical assistance to manufacturing firms. During 2007-12, for instance, a joint USAID/GIZ project selected ten Albanian textile subcontractors with high export potential and dispatched an international technology consultant to provide technical assistance on production and quality management, helping the participating firms develop an own-design collection. ${ }^{17}$ During 2004-11, GIZ Kosovo hired engineers to deliver on-the-job training to production managers in the metal-processing sector ${ }^{18}$. Donor programmes are typically implemented by local personnel; implementation may also be channeled through the relevant line ministry. For this reason, the selection of participating firms may be subject to personal connections or facilitation payments.

In Kosovo, a large share of donor-funded grants and loans to the private sector are routed through a unit of the Ministry of Trade and Industry (KIESA). In 2014, a former director of KIESA became embroiled in a corruption scandal. ${ }^{19}$ Besides grants and preferential credit, some firms have also received informal or "covert" subsidies, including the Ferronikeli smelting plant, Kosovo's largest exporter and the main employer in industry (Uberti 2014). In 2010, a violent

\footnotetext{
${ }^{14}$ In 2015, the average trade-weighted tariff rate in Albania and Kosovo were, respectively, 3.9 percent and 7 percent (MTI 2015, 48). See also WTO, Tariff Download Facility, 2016.

${ }^{15}$ Interview with firm manager from the food and beverage industry, March 2015, Ferizaj/Urosevac (Kosovo).

${ }^{16}$ Interview No. 52 with firm manager from the non-metallic minerals industry, April 2015, Prizren (Kosovo).

${ }^{17}$ Interview AL31 with programme director, GIZ Albania, July 2015, Tirana (Albania).

${ }^{18}$ Interview KS07 with programme director, GIZ Kosovo, October 2014, Pristina (Kosovo).

19 The former director was later acquitted.
} 
dispute had broken out between the largest wine producer in Kosovo and a group of local farmers who had previously supplied the firm. In a bid to resume the supply contracts and pacify the farmers, the PDK government allegedly granted a large input subsidy to the wine company, which is known to have political connections. ${ }^{20}$

In both countries, "unfair" competition from informal or semi-informal manufacturers is perceived by firms as the prime barrier to doing business (UNDP 2012, p. 44). Both economies are rife with small workshops and micro-firms operating on a more or less informal basis. These informal economies may include subsistence economic activities that were never formally incorporated, but also more established businesses that were pushed "underground" by corruption and over-regulation (Friedman et al. 2000). Either way, Danielsson (2015, p. 253) shows that informality in Kosovo "represents the unquestioned way to do business [...] for relatively less privileged businesses". ${ }^{21}$ Although less privileged, informal competitors can pose a challenge for formally registered firms. Thus, a state intervention to prop up politically connected firms by clamping down on their informal (non-politically connected) competitors effectively amounts to a special privilege - a rent. ${ }^{22}$ Since it came back to power in July 2013, the Socialist Party of Albania (PS) has made the battle against informality one of its flagship policies. Yet, there is reason to suppose that the clamp-down on informality may have been uneven, with firms paying "political contributions" to the PS benefitting more from state protection against informal competitors than the general population of firms.

We hypothesise that these (corruptively allocated) rents may promote firm performance in a variety of ways. Rents (technical assistance programmes, for instance) may promote technical learning and allow firms to increase the efficiency with which existing inputs are combined, stimulating TFP growth (H4). Rents (e.g. loans and subsidies) may also enable firms to undertake capacity expansion projects that would not otherwise have occurred, promoting investment and capital accumulation (H5). Lastly, we allow for the possibility that rents may not just stimulate investment, but also increase the returns to investment. Installing new capacity may not increase sales revenue unless a firm can secure its position against informal competitors, or learn all the necessary technical skills needed to operate a new machine tool. ${ }^{23}$

\footnotetext{
${ }^{20}$ Interview KS09 with two GIZ consultants, April 2015, Pristina (Kosovo).

${ }^{21}$ Emphasis added.

${ }^{22}$ Of course, some powerful businesses may be allowed to operate informally precisely by virtue of their political connections (Danielsson 2015). In this case, it is informal companies that earn a rent in the form of a waiver on rule enforcement.

${ }^{23}$ A good example is Kosovo's plastics and rubber industry, whose companies have suffered declining profits due to the unrestricted entry of informal competitors (Interview No. 57 with firm manager from the plastics and rubber sector, April 2015, Han i Elezit/Djeneral Janković, Kosovo).
} 
Because of these potential complementarities, we expect the marginal product of capital and labour to be higher for rent-receiving firms (H6).

[Figure 1]

Our testable hypotheses are summarised diagrammatically in Figure 1 . We now turn to a description of the data that we use to test these hypotheses.

\section{Data}

\subsection{Survey Design and Data Collection}

The data come from a novel enterprise survey of 239 privately owned, legally registered firms from the manufacturing and mining sectors in Albania and Kosovo. The survey was designed by the authors and administered during February 2015-February 2016. The companies were selected by stratified random sampling from 22 country-sectors, leading to a broader and more comprehensive coverage of industrial sectors across the two countries. In addition, the sampling scheme assigned a higher sampling probability to larger firms, resulting in a sample that accounts for a larger share of total industrial value-added. We only sampled small, medium and large enterprises, thus excluding micro-firms (with less than 10 full-time employees), many of which are legally registered but inactive. ${ }^{24}$ Additional information on sampling and survey design are presented in Appendix A.

Our sample provides a representative picture of Albania's and Kosovo's industrial economy. For each individual industrial sector, the average sampling rate is 5.6 percent. Overall, the sample accounts for about 1.6 percent of the total population of registered firms, including micro-firms, in the 22 country-sectors. Excluding micro-enterprises from the population, the Kosovar firms in the sample represent just under 40 percent of the total population of small, medium and large firms active in the 11 sectors surveyed in this country. ${ }^{25}$ Overall, the surveyed sectors comprise over 90 (81) percent of total industrial value-added produced by Kosovo (Albania). ${ }^{26}$ Our sample is thus highly representative of the population of interest.

\footnotetext{
${ }^{24}$ In both countries, it is relatively easy to establish a business. Furthermore, many registered firms are "shell" entities established to apply for grants from development agencies.

${ }^{25}$ Since, for Albania, we do not have data on the number of companies by sector and by size, we cannot perform this calculation.

${ }^{26}$ Authors' calculations.
} 


\subsection{Industrial Firm Performance}

The first chapter of the survey questionnaire ${ }^{27}$ focuses on the firm's accounting information. To avoid sensitive questions, we asked our respondents to indicate their company's sales revenue in first-differences (averaged during 2011-15), rather than in levels. We also asked questions on the current number of employees, the average annual number of new hires/lay-offs during 2011-15, the current value of the capital stock (including machinery and land) and the total investment made during 2011-15. We then used this information to recover the average percentage growth rate of the capital stock and labour force during 2011-15. ${ }^{28}$ Although this approach might introduce noise in the data, it makes the questions much more acceptable to the respondents, reducing the incidence of missing values. In addition, we obtained general demographic and legal information about the firm (ownership, age, history, etc.) and the firm owner/manager (e.g. level of education, gender, etc.).

\section{[Table 1]}

Table 1 reports descriptive statistics for some of these variables. During 2011-15, sales revenue growth ( $\Delta \ln y$ ) averaged 10.8 (5.20) percent in Kosovo (Albania). Kosovo's younger and less advanced firms are clearly experiencing catch-up growth relative to Albania's more mature firms. Similarly, Kosovo's firms grow their labour force $(\Delta \ln L)$ and capital stock $(\Delta \ln K)$ at a slightly higher rate than Albania's. In both, countries, around 14 percent of firms are (at least partially) foreign-owned. A significantly larger share of Kosovar firms in the sample are former SOEs, consistent with the greater importance of this group of firms in Kosovo's industrial economy. In post-socialist Albania, rural-to-urban migration has led to the clustering of productive activities in the capital-city region. By contrast, the pattern of productive decentralisation promoted in Kosovo under socialist Yugoslavia has largely persisted into the posttransition period. This difference is reflected in our sample (see the Capital city variable). Surprisingly, however, a significantly larger share of Kosovar firms (48 percent) report being engaged in export activities compared to Albanian firms (19 percent).

Because some respondents did not answer all the questions, the sample available for estimation is restricted to 187 observations. Across all these dimensions, however, we detect no

\footnotetext{
${ }^{27}$ The survey questionnaire is available from the authors upon request.

${ }^{28}$ To obtain the average annual percentage growth rate of labour force (and, mutatis mutandis, capital stock), we use the following geometric mean formula: $\Delta \ln L=\left(L_{2015} / L_{2011}\right)^{1 / 4}-1$.
} 
statistically significant difference between the full- and restricted-sample means. The sample used in the regression analysis is still representative of the population at large. ${ }^{29}$

\subsection{Indicators of Corruption}

Next, the survey questionnaire included questions about corruption and rents. Our perceptionbased measure of corruption is constructed based on the following question: "to what extent to you believe that corruption is widespread in the public institutions and in the delivery of public services that are relevant for your line of business?"

In contrast to previous contributions, we decided not to ask firm managers/owners to estimate the percentage of total annual sales paid in bribes (Hellman et al. 2003; Fisman and Svensson 2007), or the firm's own exposure to bribe solicitations (Seker and Yang 2014). As is well known, respondents have little to gain from answering direct questions about corruption truthfully if they are concerned about being identified or looking bad (Clarke et al., 2015. Using data from Romania, for instance, Azfar and Murrell (2009) find that reticent managers underreport bribery by about one third. To mitigate the problem of social desirability bias, we rely on an indirect question, asking respondents about sector-level corruption as a roundabout way to elicit information about the firm's own experience with corruption. ${ }^{30}$

In so doing, we did not ask specifically about the frequency with which bribe solicitations occur in the firm's line of business, as in previous research (Athanasouli and Goujard 2015, Hanousek and Kochanova 2016). Rather, our question is deliberately general insofar as it does not distinguish between the frequency of bribe solicitations and the magnitude of individual bribes. Rather, we interpret the answers to our question as providing a proxy measure of the total bribe transacted by the firm. ${ }^{31}$

That said, we acknowledge that the interpretation of our indicator is somewhat ambiguous. Furthermore, corruption perceptions may be systematically biased by factors such as gender or education (although we explicitly control for these potential sources of perception bias in all the regressions reported below). These limitations, however, apply to all perception-based indicators rather than just to our own (Olken 2009). Similar considerations underpin the formulation of our questions regarding rents, which we shall introduce shortly.

\footnotetext{
${ }^{29}$ The t-tests reported in Table 1 can never reject the null that the means reported in columns (c) and (d) are equal.

${ }^{30}$ To the extent that the responses also reflect sector-level events, our indicator would still be capturing relevant information. Even if the respondent does not pay bribes, operating in a business environment in which bribe solicitations are widespread creates uncertainty. As a result, managers might have to devote time to anticipating and pre-empting bribe solicitations, and resources may have to be set aside as insurance. By asking firms about their perceptions of sector-level events, our indicator captures the full magnitude of the corruption effect

${ }^{31}$ Conceptually, the total bribe transacted equals the frequency of bribes times the magnitude of individual bribes.
} 
[Figure 2]

The interviewees provided a response to our corruption question on a 5-point ordinal Likert scale, with the option of providing a "don't know" (=0, or missing) answer. Each question was accompanied by a short rubric describing the meaning of each response category. The frequency of non-missing responses is plotted in Figure 2. Unsurprisingly, as much as 63 (66) percent of respondents in Kosovo (Albania) indicated that corruption was "somewhat" (CORR = 4 ) or "extremely widespread" (CORR $=5$ ) in their line of business, and less than 6 (12) percent of Kosovar (Albanian) firms reported "little" (CORR =2) or "no" (CORR $=1)$ corruption.

In the analysis, we used dummies to denote the ordinal responses, grouping $\operatorname{CORR}=1-$ 2 (little corruption) and $C O R R=4-5$ (a lot of corruption) responses together two by two. The intermediate category $(\operatorname{CORR}=3)$ is coded separately as a stand-alone category. Thus, $\operatorname{Corr}$ is a dummy that takes the value 1 when respondents answer 4 or 5; IntCorr takes the value 1 when CORR equals 3; and NoCorr takes the value 1 when the response is 1 or 2 (and 0 otherwise). Throughout our analysis, Corr serves as the reference category. "Don't know", or "missing" $(C O R R=0)$, responses are controlled for with a separate dummy, which (reassuringly) enters insignificant in almost all specifications. Figure 3 shows that, on average, "non-corrupt" $($ NoCorr $=1)$ firms grow at a slightly higher rate than "corrupt" firms, but this difference is not statistically significant. Since growth and corruption (perceptions) may be jointly influenced by omitted factors, the sample mean difference cannot be given a causal interpretation. Thus, we conduct a multiple regression analysis.

[Figure 3]

\subsection{Rent Indicators}

To construct indicators of rent allocation at the sector level, we presented our respondents with the statements reported in Table 2. The respondents can then indicate various degrees of agreement or disagreement with these statements on a 5-point Likert scale, plus a "don't know" option. As with CORR, we replaced each of the four RENT variables with three dummies (Rent, IntRent and NoRent), treating NoRent as the reference. The dummy Rent is defined to take the value 1 when the response to the underlying question is 1 or 2 (or 4 or 5 in the case of question 1.4). For all four types of rent, the Rent $=1$ category describes a business environment 
in which rent allocations are (very) prevalent. All the specifications examined below control for "don't know" and intermediate-category responses $(R E N T=3$, i.e. IntRent $=1)$ separately for each of the four variables. As shown in Table 2, a substantial minority of respondents in both countries indicated that firms in their line of business earn rents. For instance, 20 percent of Albanian industrial firms indicated that they (strongly) agreed with question 1.1 ("in general, your line of business enjoys significant protection from import competition").

[Table 2]

[Table 3]

A cross-tabulation of NoCorr and Rent is shown in Table 3. The data suggest that, if firms are to qualify for preferential treatment, they must engage in corrupt transactions. To be sure, many (indeed, the majority) of firms take part in rent-seeking contests and pay bribes but fail to capture rents. Yet, very few "non-corrupt" firms (indeed, none, when it comes to technical assistance) reported rent allocations in their line of business. This evidence is consistent with the notion that rent flows are typically activated by bribe flows. Figure 4 shows that rent recipients specifically, those that benefit from technical assistance, loans or subsidy programmes - grow their sales revenue at a significantly higher rate than other firms. ${ }^{32}$ Yet, again, we cannot interpret the mean differences as identifying a causal effect.

[Figure 4]

One of the objectives of the empirical analysis is to test whether rents enhance the marginal product of labour and capital. Interacting the four RENT variables with $\Delta \ln K$ and $\Delta \ln L$ would generate an unwieldy number of interaction terms. Thus, to simplify the data and consume fewer degrees of freedom, we also perform a (tetrachoric) factor analysis on the four Rent dummies (Hamilton 2013). The technical details are discussed in Appendix B.

The analysis retains two latent factor (called $f 1$ and $f 2$ ), which collectively explain 71 percent of the total variance in the Rent dummies. The partial correlation coefficients between the (promax-rotated) factor scores and the observed Rent variables are presented diagrammatically in Figure 5. The factors admit a clear and intuitive interpretation. The technical assistance and loans/subsidy dummies load heavily on $f 1$, but very little on $f 2$. Thus, we

\footnotetext{
${ }^{32}$ The $p$-values of the t-tests for the equality of the means are, respectively, 0.043 (top-right quadrant) and 0.037 (bottom-left quadrant).
} 
interpret $f 1$ as a measure of the degree to which firms receive direct rents from the state. By contrast, the import protection and unfair competition dummies load more heavily on $f 2$. Thus, we interpret $f 2$ as a proxy for what we may call (quasi-monopoly) rights. These rights are equivalent to direct rent transfers in that, once allocated, they generate rents for their holders.

[Figure 5]

Having presented the survey and the survey data, we now turn to the empirical analysis, which seeks to test hypotheses $\mathrm{H} 1$ through $\mathrm{H} 6$ (see Figure 1).

\section{Firm Productivity}

\subsection{Model Specification and Estimation}

Consistent with our hypotheses, we allow bribes and rents to influence all the possible drivers of firm output - that is, the rate of total-factor productivity growth (as per $\mathrm{H} 1$ and $\mathrm{H} 4$ ); the rate of factor accumulation ( $\mathrm{H} 2$ and $\mathrm{H} 5$ ), and the marginal product of factor inputs ( $\mathrm{H} 3$ and $\mathrm{H} 6$ ). In this section, we focus on the influence of bribes and rents on output growth, holding constant the rates of factor accumulation. Section 5 examines how bribes and rents affect the firm's investment and hiring decisions.

To test $\mathrm{H} 1$ and $\mathrm{H} 4$, we estimate the following augmented Cobb-Douglass production function in first-differences:

$$
\Delta \ln y_{i}=\alpha \Delta \ln K_{i}+\beta \Delta \ln L_{i}+\varphi C_{\text {CORR }}+\vartheta R E N T_{i}+\omega \text { Dum }_{i}+\gamma \boldsymbol{X}_{i}+\tau \text { Albania }_{i}+u_{i}
$$

In equation (1a), the component of output growth that cannot be imputed to the growth of the labour force and capital-equipment stock - that is, TFP growth - is allowed to depend on the rent and corruption variables (in levels) presented in section 3. Across out specifications, we use the NoCorr and Rent dummies to measure bribes and rents. $\mathbf{D u m}_{i}$ is a vector of dummies capturing "don't know" and intermediate-category responses (see section 3). Albania $i$ is a country fixed-effect dummy controlling for country-level characteristics related to history, institutions and culture. The mean difference in performance between Kosovar and Albanian firms (see Table 2) is accounted for by this term, which enters as insignificant across most of our specifications. Lastly, $u_{i}$ is a firm-specific random disturbance.

If certain firm characteristics (e.g. capital city location) are conducive to growth and also make it more likely for firms to engage in corrupt transactions (or receive rents), the omission of 
these factors would cause the OLS estimator of $\varphi$ (or $\vartheta$ ) to be biased and inconsistent. Equally worrying is the possibility that omitted determinants (e.g. the respondent's gender or level of education) may bias the parameter estimates by jointly influencing firm performance and the respondent's perceptions of corruption and rent allocations (Olken 2009).

To mitigate these sources of endogeneity, we include $\boldsymbol{X}_{i}$, a set of potential determinants of firm performance discussed in the existing literature. The log of the firm's age controls for convergence effects. ${ }^{33}$ The share of qualified engineers in the total 2015 workforce (in logs) and the number of years of education of the firm's top manager (in levels) control for human capital and management quality. To account for the influence of local gender norms, we include a dummy that takes the value 1 when the company's top manager/owner is female. ${ }^{34}$ We also control for the possibility that foreign equity participation, measured using a dummy variable, may facilitate the uptake of superior technologies and processes (Estrin and Uvalic 2016). To take into account the legacy of state-ownership (Frydman et al. 1999), we include a dummy that takes the value 1 if a firm was a former SOEs or a significant share of its fixed assets was purchased in a privatisation sale. The Export dummy, which takes the value 1 for exporting firms, captures the effects of exposure to international competition (Tybout 2003). Lastly, a dummy for capital-city location controls for agglomeration effects.

Some of these factors (e.g. firm age, capital city location) may also affect the likelihood of bribe solicitations. Others (e.g. education, gender) may influence our respondent's perceptions of corruption and preferential treatment. If so, their inclusion performs a particularly important controlling function. Nevertheless, inferring causality using perception-based indicators remains a daunting task. Even in the absence of omitted influences, our variables of interest are measured with error. Furthermore, perceptions of corruption and special privileges may be influenced directly by the firm's own performance, even after controlling for various determinants of sales growth. Since valid instruments are hard to come by, the best we can do is explore the correlations in the data. To the extent that we give them a causal interpretation, we only do so under these very restrictive assumptions.

Next, to test hypotheses $\mathrm{H} 3$ and $\mathrm{H} 6$, we allow the output elasticities with respect to labour and capital to depend linearly on the corruption and rent variables: $\alpha=\alpha_{0}+$ $\varphi_{K} \operatorname{CORR}_{i}+\vartheta_{K} R E N T_{i}$ and $\beta=\beta_{0}+\varphi_{L} \operatorname{CORR}_{i}+\vartheta_{L} R E N T_{i}$. Substituting these expressions into equation (1a) leads to a regression model with interaction terms:

\footnotetext{
${ }^{33}$ Age is defined as years since the firm's legal establishment. The logarithmic specification, which is common in the firm productivity literature (e.g. Gatti and Love 2008) allows for productivity growth to decline at a decreasing rate over time. For former SOEs, the year of establishment is taken to be the year in which the firm was privatised.

${ }^{34}$ Only 5 (14) percent of Kosovo's (Albania's) sampled firms were run or owned by a female top manager.
} 


$$
\begin{array}{r}
\Delta \ln y_{i}=\alpha_{0} \Delta \ln K_{i}+\beta_{0} \Delta \ln L_{i}+\varphi \operatorname{CORR}_{i}+\varphi_{K} \operatorname{CORR}_{i} \cdot \Delta \ln K_{i}+\varphi_{L} \operatorname{CORR}_{i} \cdot \Delta \ln L_{i}+\vartheta R E N T_{i} \\
+\vartheta_{K} R E N T_{i} \cdot \Delta \ln K_{i}+\vartheta_{L} R E N T_{i} \cdot \Delta \ln L_{i}+\omega \operatorname{Dum}_{i}+\gamma \boldsymbol{X}_{i}+\tau \text { Albania }_{i}+u_{i}
\end{array}
$$

In this more flexible specification, bribes and rents are allowed to moderate the output effect of marginal factor additions. The inclusion of these interaction terms is a theoretical and empirical novelty of this paper.

In estimating equations (1a) and (1b) by OLS, we take into account the sampling design presented in section 3. In order for the OLS variance estimator to be unbiased and efficient, we incorporate information on the sample's stratification and make a finite population correction (StataCorp 2013, p. 4). To obtain unbiased point estimates, we specify a sampling weight that takes into account the probability of each observation being selected into the sample (Levy and Lemeshow 2008, p. 335). ${ }^{35}$ The linearised variance estimator employed is robust to heteroskedasticity (StataCorp 2013, p. 6). Additional details are provided in Appendix C.

\subsection{Regression Results: Bribes}

We begin by examining the relationship between corruption and TFP (that is, H1). The estimates of equation (1), omitting RENT, are displayed in Table 4. Let us first interpret the Cobb-Douglass coefficients. While the output elasticity w.r.t. capital $(\alpha=0.448)$ is positive and significant at 1 percent, in line with theoretical expectations, the output elasticity w.r.t. labour is statistically indistinguishable from zero. Labour inputs are at the so-called "intensive margin", implying zero marginal productivity (Wetzstein 2004, p. 196). In low-middle income economies such as Albania and Kosovo, labour is typically present in uneconomically large proportions relative to capital. If the average company is overstaffed, hiring the marginal worker should be expected to have no additional effect on output, even in the presence of spare capacity. $\alpha+\beta=0.456$ is substantially lower than 1 , implying that industrial production in these two countries is subject to (sharply) decreasing returns to scale.

Based on model (1), the average rate of TFP growth - the rate of output growth achieved by the average firm when $\Delta \ln K=\Delta \ln L=0$ - is 1.9 percent for Albania ( $p$-value $=0.469$ ) and 4.7 percent for Kosovo ( $p$-value $=0.056$ ). For Albania, this estimate implies that the average industrial firms effectively achieved zero growth in productivity during 2011-15. Reassuringly,

\footnotetext{
${ }^{35}$ Within strata, companies are not sampled randomly but based on a measure of firm size (number of employees). Since firm size may be related to the dependent variable (output growth), ignoring the sampling probability may lead to sample selection bias.
} 
these estimates are qualitatively consistent with the national accounts statistics discussed in section 2 .

[Table 4]

Let us now turn to the main coefficients of interest. Relative to firms that operate in a line of business where corruption is (extremely) widespread (CORR $=4,5)$, the firms that operate in a corruption-free environment grow much faster. Holding everything else constant, "noncorrupt" firms grow their TFP at an average annual rate that is over 12 percentage points higher than that of "corrupt" firms. This is much higher than the 2 percentage-point difference reported in Figure 3. This finding is consistent with the argument underpinning hypothesis H1: corruption and rent-seeking divert managerial effort away from factor coordination, reducing the efficiency with which inputs are combined. ${ }^{36}$

The estimated coefficients on the other control variables are either statistically insignificant or, if significant, they enter with the "correct" sign. ${ }^{37}$ These regressors perform an important controlling function. Omitting them leads to a 18 percent drop in the magnitude of the estimated coefficient on NoCorr. ${ }^{38}$ Thus, failing to control for potential joint determinants of corruption and firm performance would introduce downward bias in the estimated coefficient on corruption.

The coefficient on NoCorr in Model (1) may still be underestimating the productivity costs of corruption if at least some "corrupt" firms benefit from the "greasing" effects of paying bribes. To separate out these "greasing" effects, model (2) adds interaction terms between NoCorr, on the one hand, and $\Delta \ln K$ and $\Delta \ln L$, on the other. The estimated coefficient on NoCorr $\cdot \Delta \ln K$ is statistically significant at the 10 percent level. The magnitude of the point estimate implies that, for the group of "non-corrupt" firms, the average output elasticity w.r.t. capital is 0.416 lower than in the (much larger) group of "corrupt" firms. For "corrupt" firms, the estimate of $\alpha$ is 0.460 , higher than for the average firm (0.433). For "non-corrupt" firms, however, $\alpha$ is $0.044(=0.460-0.416)$ and is statistically insignificant. In the absence of corruption, the marginal product of an additional unit of capital is effectively zero. This finding is in line with hypothesis $\mathrm{H} 3$, namely that investment and corruption are sometimes complements.

\footnotetext{
${ }^{36}$ Note that operating in an environment with "intermediate" levels of corruption, by contrast, is not associated with a productivity dividend.

${ }^{37}$ Former SOEs are generally much older than the private firms established de novo in the post-transition period. It is thus to be expected that they should grow their TFP at a lower rate.

${ }^{38}$ This model is not reported to save space.
} 
Being able to resort to corruption, in other words, is a necessary condition for firms to clear various bottlenecks and bring a machine tool or assembly line into full operation. We do not observe a similar complementarity between corruption and the firm's hiring decisions at statistically significant levels.

Although corruption enables firms to cut through the red tape and "get things done", it also places a substantial burden on management time. When netting out the "greasing" effect of corruption (as in model 2), the estimated TFP loss due to being "corrupt" increases from 12.6 (model 1) to 20.2 (model 2). Thus, the net positive effect of being "non-corrupt" $\left(\partial \Delta \ln y / \partial N o \operatorname{Corr}=\varphi+\alpha_{1} \overline{\Delta \ln K}+\beta_{1} \overline{\Delta \ln L}=11.03, p\right.$-value $\left.=0.000\right)$ is still large, and quantitatively consistent with the findings of model 1 (12.58).

Since only a small minority of Kosovar (6 percent) and Albanian (12 percent) firms are "non-corrupt", including NoCorr and the two interaction terms in the regression raises the model's $\mathrm{R}^{2}$, relative to an unreported benchmark that omits them, by less than four percentage points. Corruption per se does not account for a very large share of the variation in performance across firms. The rents extracted by some bribe-payers might explain why some "corrupt" firms perform better than other, equally "corrupt", firms.

\subsection{Regression results: Rents}

To investigate this possibility, the models reported in Table 5 estimate the relationship between output growth and the rent variables. Controlling for the "rent side" of corrupt transactions in the regression increases the $R^{2}$ of the model by as much as 13 percentage points. Industrial policy rents, which tend to be allocated corruptively, are thus highly consequential in shaping patterns of firm performance in Albania and Kosovo. The coefficients on the four Rent dummies (model 1) are all positive, and two of them (those associated with questions 1.2 and 1.4) are quite large and highly significant. Ceteris paribus, firms who benefit from technical assistance programmes or whose "sectors" receive substantial protection from "unfair" competition grow their TFP at an average annual rate that is 10-11 percentage points higher than that of firms that do not benefit at all from such rents. This finding is consistent with hypothesis $\mathrm{H} 4$ - namely, that (corrupt) rent transfers promote firm productivity.

The mechanisms through which technical assistance programmes enhance TFP growth are clear. A politically orchestrated clampdown on informal competitors, meanwhile, might be presumed to ease competitive pressures on the beneficiary (formal) firms, allowing them to 
absorb spare capacity and grow their sales revenues holding constant the quantity of labour and capital. $^{39}$

[Table 5]

Similar results are obtained replacing the four Rent dummies with the factor scores obtained from the factor analysis (model 2, Table 5). The coefficients on both $f 1$ and $f 2$ are positive and statistically significant at conventional levels. If these were causal effects, a standard-deviation increase in $f 1(f 2)$ would lead to a $3.7(2.6)$ percentage-point increase in the firm's rate of TFP growth, holding everything else constant - an effect that corresponds to 0.26 (0.18) standard deviation of $\Delta \ln y$.

Model 3 adds an additional control dummy for the Kosovar firms that are located in the newly established free economic zones or in the former socialist industrial zones. ${ }^{40}$ Kosovo's economic zones are one of the main pillars of its "cluster-based" industrial policy (RoK 2016). ${ }^{41}$ There are currently five special economic zones. ${ }^{42}$ Bribes and personal connections are likely to play an important role in regulating entry. If admitted, a firm enjoys a range of valuable "perks", including near-free land-use rights, access to quality infrastructure, exposure to potential positive spill-overs, some limited tax holidays and, crucially, guaranteed 24-hour electricity supply. ${ }^{43} 28$ percent of the firms surveyed in Kosovo are located in a free economic zone. As shown in column 3, firms in these privileged locations post an average annual rate of productivity growth that is almost 7 percentage points higher than firms located elsewhere, after netting out the (negative) effect of bribery and the (positive) effect of other rent allocations.

Next, to examine hypothesis $\mathrm{H} 6$, we estimate a fully specified model that allows $f 1$ and $f 2$ to interact with $\Delta \ln K$ and $\Delta \ln L$ (column 4). Reflecting the possibility that rents and factor accumulation may be complements, this model allows the output elasticities of capital and labour to depend linearly on the allocation of rents (see equation $1 \mathrm{~b}$ ). In this specification, the

\footnotetext{
${ }^{39}$ Several firms interviewed in Kosovo report operating at 10-40 percent of their nameplate capacity (e.g. interviews No. 7, 15, 21, 34, March-April 2015, various locations, Kosovo).

${ }^{40}$ Albania does not have a working system of free economic zones. In 2005-13, Albania did try to establish such zones, but with no success.

${ }^{41}$ Interview KS013 with head of Department of Industry, Ministry of Trade and Industry, December 2014, Pristina, Kosovo.

${ }^{42}$ Some of zones, however, were inactive at the time of the survey. The zones may be established by a local municipality, which then becomes responsible for building the facility and granting access to businesses on a competitive basis.

${ }^{43}$ Since firms located in the former socialist-era industrial zones also benefit from round-the-clock electricity supply (which is one of the main benefits of being located in a free economic zone), we code these firms together with the firms located in the newly established zones. At the time of the survey, the $10 \mathrm{kV}$, high-tension lines, which guarantee round-the-clock supply were only available in the free zones and in the former industrial zones.
} 
estimated coefficients on $f 1$ and $f 2$ lose statistical significance. Absent additional increases in labour and capital $(\Delta \ln K=\Delta \ln L=0)$, rents alone do not increase output growth at statistically significant levels. Increasing the rate of growth of capital-equipment stock by, say, 1 percentage point, however, raises the estimated coefficient on $f 1(f 2)$ by $0.797(0.144)$. For $f 1$ (but not for $f 2$ ), this increment is statistically significant at the 10 percent level. Consistent with $\mathrm{H6}$, this finding suggests that at least some rents (technical assistance, loans and subsidies) exhibit a relation of complementarity with respect to investment. ${ }^{44}$

[Figure 6]

Put differently, an increase in $f 1$ (but not in $f 2$ ) increases the magnitude of the firm's output elasticity w.r.t. capital - the firm's returns from installing an additional unit of capital equipment. Figure 6 (left-hand panel) plots the relationship between the estimated output elasticity and the rent index $(f 1)$. In line with $\mathrm{H} 6$, firms that receive more industrial policy rents (technology consulting, loans and subsidies) are in a better position to benefit from additional investment than firms that do not receive such rents.

Note that an increase in $f 1$ (but not in $f 2$ ) leads to a statistically significant reduction in the output elasticity w.r.t. labour (right-hand side panel in Figure 6). When $f 1$ increases by a standard deviation above the sample mean (marked by a vertical line in Figure 6), $\beta$ becomes significantly negative, eating away at the positive gains in output growth associated with industrial policy rents (note, however, that the sum of these effects is always positive, as implied by the marginal effect curve for capital being steeper than that for labour). This finding runs counter to our expectations under H6. A possible explanation is that access to grants and subsidies may come with strings attached. For instance, rent recipients may be under pressure to hire politically connected workers as part of a quid pro quo with politicians.

Two pieces of anecdotal evidence are consistent with this interpretation. In Albania, an employment promotion programme run by the Ministry of Labour provided support to labourintensive firms by subsidising salaries and pension contribution for the workers hired under the scheme. The programme, however, was reportedly mired in corruption and patronage, with participant firms being under intense pressure to hire party clients. ${ }^{45}$ Since party clients are not

\footnotetext{
${ }^{44}$ On average (when $\Delta \ln K$ and $\Delta \ln L$ are at their sample means), the marginal effect of $f 1(12.3, p$-value $=0.010)$ and $f 2(8.1, p$-value $=0.035)$ are again positive and statistically significant, consistent with previous results.

${ }^{45}$ Interview No. 16 with manager from the textile and apparel industry, May 2015, Tirana, Albania.
} 
necessarily the most efficient workers, the returns from fielding the marginal worker may well have been negative.

In February 2011, a foreign-owned food-processing company decided to relocate to the city of Prizren, Kosovo. Reportedly, the move was prompted by an "informal agreement" struck by the firm with the local PDK mayor. The deal granted the company a 20-year leasehold free of charge over a plot of public land in the city's outskirts. In exchange, the company committed to hiring local workers. ${ }^{46}$ While the plot's convenient location, with easy access to Kosovo's recently built highway to Albania, might have raised the company's ability to gain from further capital investments, the conditions attached might have led to over-staffing, pushing the firm's output elasticity w.r.t. labour below the zero mark. ${ }^{47}$

The models reported in Table 5, in addition, reproduce all of our earlier findings. Even after controlling for the allocation of rents, and for the moderating influence of rents on the output elasticities, the coefficient on NoCorr $\cdot \Delta \ln K(=-0.389)$ is still negative and statistically significant, suggesting a complementarity between corruption and investment. In addition, this specification (and those reported in columns 1-3) suggests that there may also exist a complementarity between corruption and workforce expansion, with "non-corrupt" firms displaying a substantially lower output elasticity w.r.t. labour than "corrupt" firms, in line with hypothesis H3. When we allow for some "corrupt" firms to: 1. benefit from the "greasing" effects of corruption, and 2. earn rents, the estimated costs of corruption, in TFP terms, increase further to 21.6 (up from 20.2 in model 2, Table 4). The net effects of being "non-corrupt", however after accounting for the beneficial effects of corrupt "greasing" and rents - is only about half as large (10.0), but still positive and significant, and quantitatively consistent with previous findings (e.g. 12.6 in model 1, Table 4). To investigate robustness, Appendix D presents and discusses some alternative model specifications to the one reported in column 4, Table 5.

Taken together, the regression results broadly confirm our expectations that, although corruption and rent-seeking are generally harmful for productivity (H1), the winners of rentseeking contests - the firms that are able to capture rents, typically by corrupt means experience beneficial improvements in productivity (H4). In addition, the results provide some support to our hypothesis that both bribes and rents may enhance the returns on investing in capital equipment (H3 and H6), either because they allow firms to "grease the wheels" of the bureaucracy and clear various bureaucratic bottlenecks (bribes) or because they provide skills or

\footnotetext{
${ }^{46}$ Interview No. 51 with manager from the food and beverages industry, April 2015, Prizren, Kosovo.

${ }^{47}$ That said, it is very possible that, on net, the company might have benefitted from this (informally negotiated) rent allocation.
} 
other resources that are complementary to fixed capital (rents). In fact, the presence of at least some corruption in the firm's operating environment appears to be a necessary condition for returns on investment to be non-zero.

That said, we fail to identify a systematic complementarity between bribes, rents and workforce expansion. While bribery may indeed allow firms to benefit from hiring the marginal worker, rent allocations (many of which may come with strings attached) may further aggravate the already endemic problem of overstaffing.

\section{Factor Accumulation}

\subsection{Model Specification}

Next, we examine the impact of bribes and rents on the firm's decisions to mobilise additional units of labour and capital. In particular, we test hypotheses H2 ("corruption reduces investment") and H5 ("rents promote investment"). We have no strong priors as to the impact of bribes and rents on labour addition.

To test these hypotheses, we augment an unconditional factor demand equation (in first differences) with our rents and corruption variables, plus the vector of controls $\left(\boldsymbol{X}_{i}\right)$ included in eq. (1). Firms are assumed to be price-takers, which implies that input and output prices (and their rates of change) are exogenous to the firm's decision to hire capital and labour. Absent detailed data on wages, interest rates and output prices, we use country-sector and location fixed effects as proxies for the rate of change of market prices. This approach rests on a number of plausible assumptions - namely, that labour and capital markets are defined at the local (city) level $^{48}$, and that trends in output prices are country-sector specific. Besides prices, the fixed effects flexibly control for any other location- (geography, institutions) and sector-specific (technology) effects that may not necessarily operate through prices.

The estimating equations are thus:

$$
\begin{aligned}
& \Delta \ln K_{i l s c}=\pi_{K} \operatorname{CORR}_{i l s c}+\mu_{K} R E N T_{i l s c}+\omega_{K} \text { Dum }_{i l s c}+\gamma_{K} \boldsymbol{X}_{i l s c}+\tau_{l}+\sigma_{s c}+u_{i l s c} \\
& \Delta \ln L_{i l s c}=\pi_{L} \operatorname{CORR}_{i l s c}+\mu_{L} R E N T_{i l s c}+\omega_{L} \text { Dum }_{i l s c}+\gamma_{L} \boldsymbol{X}_{i l s c}+\tau_{l}+\sigma_{s c}+v_{i l s c}
\end{aligned}
$$

where $\Delta \ln K_{\text {ilsc }}\left(\Delta \ln L_{\text {ilsc }}\right)$ is the percentage growth rate of change of the capital-equipment stock (labour force) for firm $i$ in city $l$, sector $s$ and country $c$, and $\tau$ and $\sigma$ are city and country-sector

\footnotetext{
${ }^{48}$ In Albania and Kosovo, it is plausible to assume that workers are imperfectly mobile. Also, levels of bank penetration tend to vary sub-regionally.
} 
fixed-effects, respectively. $u_{i l s c}$ and $v_{i l s c}$ are random disturbances. Because of fewer missing data, the sample available for estimating eq. (2) is slightly larger than that used to estimate eq. (1).

\subsection{Regression Results}

The estimates of the capital (columns 1-2) and labour (columns 3-4) demand equations are reported in Table 6. Throughout models 1-4, the location and country-sector effects enter as statistically significant at conventional levels, in line with theoretical expectations. The coefficients on the control variables are included but not reported to save space.

Let us now focus on the variables of interest. Corruption appears to be unrelated to the rate at which Albanian and Kosovar firms accumulate capital, a finding that runs counter to hypothesis $\mathrm{H} 2$. A possible explanation is that the main opportunity costs faced by bribe-paying firms are those associated with the time spent negotiating and transacting bribes, rather than the monetary costs of the bribe itself. Put differently, the cost of corruption takes the form of forgone productivity improvements owing to firm managers' diverting effort away from management tasks. No investment opportunities appear to be forgone as a result of managers embarking on "greasing" and rent-seeking efforts. This result resonates with existing evidence from transition economies (Hellman et al. 2003; Asiedu and Freeman 2009). In addition, we find no evidence to suggest that "corrupt" firms hire additional labour to offset the productivity loss induced by corruption. In fact, the estimated coefficients on NoCorr are positive, albeit insignificant, in both model (3) and (4), consistent with previous findings from Latin America suggesting that corruption may decrease employment in firms (Beltràn 2016).

[Table 6]

Unlike rent-seeking itself, the outcome of rent-seeking contests does modify the investment and hiring plans of Albanian and Kosovar firms. The direction and magnitude of the effect, however, depends on the type of rent. In line with $\mathrm{H} 5, f 1$ is positively related to the growth rate of personnel and capital equipment, suggesting that loans, subsidies and the provision of technical assistance create incentives for firms to invest and hire more workers. The magnitude of this effect is economically relevant: a standard-deviation increase in $f 1$ is associated with a 2.1 (4.0) percentage-point increase in the growth rate of the capital stock (labour force), which corresponds to 17.5 (22.8) percent of a standard deviation. The significant 
effect of $f 1$-type rents on personnel growth is consistent with previous findings suggesting that rent allocations to firms may come with "strings attached" (such as the hiring of politically connected workers), leading to labour being over-abundant and thus productivity-reducing at the margins.

In contrast, $f 2$ is negatively related to the growth rate of both production factors: a standard-deviation increase in $f 2$ is associated with a drop in capital-equipment (personnel) growth of 2.2 (2.9) percentage points, or 18.5 (16.7) percent of a standard deviation. Rents in the form of protection from foreign and domestic (informal) competition appear to create blockages along the firm's expansion path. This finding runs counter to hypothesis H5. Similarly, we find that, conditional on other rent flows, firms located in special economic zones undertake less capacity expansion, both in terms of capital and labour. As shown in the models reported in Table 5, political protection from competitors and a favourable location help firms improve productivity. Yet, it appears that productivity gains merely induce "thrift". Acquiring the ability to produce output more efficiently leads Albanian and Kosovar firms to economise on the use of factor inputs. In other words, rent-receiving firms appear to substitute productivity-enhancing rents for labour and capital.

\subsection{Total Effects}

By changing the rate of factor addition, rents (but not corruption) exert an "indirect" impact on sales growth. This mechanism adds up to the "direct" productivity effect examined in section 4. So what is the total effect of rents on firm performance? The answer is not straightforward. $f 1$ type rents (technical assistance, loans and subsidies) promote capital and labour mobilisation, while increasing the marginal returns from investment. Yet, they also push the output elasticity w.r.t. labour into the negative region (model 4, Table 5). In contrast, $f 2$-type rents (protection from import and informal competition) decrease the pace of capital and labour accumulation, slowing down the rate of output growth. Yet, at the same time, they also exert a positive impact on TFP and, thereby, output growth. In contrast to $f 1$-type rents, $f 2$-type rents do not exert any moderating influence on factor-specific productivities. In both cases, different sub-effects push in different directions.

To estimate the overall effect of rents, we examine the total derivative of $\Delta \ln y$ with respect to $R E N T$, applying the chain rule:

$$
\frac{d \Delta \ln y}{d R E N T}=\frac{\partial \Delta \ln y}{\partial R E N T}+\left(\frac{\partial \Delta \ln y}{\partial \Delta \ln K} \cdot \frac{d \Delta \ln K}{d R E N T}\right)+\left(\frac{\partial \Delta \ln y}{\partial \Delta \ln L} \cdot \frac{d \Delta \ln L}{d R E N T}\right)
$$


Computing the partial derivatives using equations (1b), (2a) and (2b), and substituting them into equation (3), we obtain the following expression:

$$
\frac{d \Delta \ln y}{d R E N T}=\left(\vartheta+\vartheta_{K} \Delta \ln K+\vartheta_{L} \Delta \ln L+\alpha_{0} \mu_{K}+\beta_{0} \mu_{L}\right)+\left(\vartheta_{K} \mu_{K}+\vartheta_{L} \mu_{L}\right) R E N T
$$

which shows that the total average marginal effect of rents on output growth depends linearly on the magnitude of rent allocations, but also on the speed of factor accumulation. Table 7 evaluates this derivative at different values of $R E N T, \Delta \ln K$ and $\Delta \ln L$. Focusing on the "average" Albanian/Kosovar firm, the first row holds these three parameters constant at the sample means. The following rows increase or decrease each parameter one by one by a standard deviation.

[Table 7]

Across different types of firms (including for the "average" firm), the total effect of the rents captured by $f 1$ (technical assistance, loans and subsidies) is positive and statistically significant. Of course, rent allocations may come with "strings attached" (e.g. the hiring of politically connected, unproductive workers). Yet, this detrimental effect of rents is more than offset by the benefits that accrue to firms not only through higher investment but also through superior returns from investment. Confirming previous findings, however, the total effect in overstaffed firms $(\overline{\Delta \ln L}+s d(\Delta \ln L))$, and in firms that do not invest much $(\overline{\Delta \ln K}-$ $s d(\Delta \ln K))$, is considerably smaller in magnitude. Another noteworthy results is that the estimated total effects of $f 1$-type rents is not subject to declining marginal returns: even a standard-deviation change in the volume of rent allocations $(\overline{R E N T} \pm s d(R E N T))$ does not significantly decrease the output effect of a marginal allocation.

The overall story is quite different when it comes to $f 2$-type rents. Conditional on a broad range of assumptions, the total output effect of protection from unfair competition and import protection is statistically indistinguishable from zero. The firms that secure these rents engage in "thrift": they become more productive faster, but they also slow down the rate at which they mobilise additional inputs, with no overall change in the rate of output growth (remember the results in Table 6). 
In sum, the rents extracted by Albanian and Kosovar firms have heterogeneous effects on performance, depending on the type of rent awarded. Crucially, the growth premium earned by rent-recipients is likely to be offset by the costs incurred in the course of seeking the rent - the costs of corruption. If the estimated coefficients measured a causal effect, a standard-deviation increase in $f 1$ would lead to an increase in output growth of around 4 percentage points (Table 7) - an effect that we interpret as resulting from the firm's winning a rent-seeking contest and securing a rent. Nevertheless, avoiding corruption and rent-seeking altogether saves the firms considerable costs, raising the rate of output growth by up to 10 percentage points (Tables 4 and 5). ${ }^{49}$

\section{Conclusion}

Two main sets of conclusions emerge from the evidence presented in the preceding sections. First, the effects of corruption on the performance of Albanian and Kosovar firms operates through a variety of different channels, some of which point in opposite directions. Allowing corruption to influence the returns from the marginal unit of labour and capital, we discovered economically relevant complementarities between corruption and investment. In Albania and Kosovo, paying bribes may be necessary for firms to "grease the wheels" of the bureaucracy, resolve a range of bottlenecks, and realise the gains from installing new capital equipment. Corruption was also found to have no chilling effect on investment, in line with previous findings from the micro literature (Hellman et al., 2003). ${ }^{50}$ That said, corruption is associated with a large cost in productivity terms. In line with the existing literature, we explained this finding by suggesting that negotiating and concluding corrupt transactions absorbs management time, diverting human resources away from essential supervisory tasks. In Albania and Kosovo, the costs of negotiating and paying bribes override the beneficial, "problem-solving" effect of corruption by a large margin.

Second, bribes cannot be studied in isolation from rents. Although firms often pay bribes to get public officials to do what they should do anyway ("grease the wheels"), they may also pay bribes to seek special privileges - that is, rents. Rents, in turn, may confer growth- and productivity-enhancing benefits on the firms that succeed in securing them. Using novel perception-based indicators of rent allocation, we presented suggestive evidence that shows

\footnotetext{
${ }^{49}$ We stress "up to" because CORR measures all types of bribery - those intended to "grease the wheels" in the face of extortion by public officials, and those intended to buy special favours (rents) from politicians.

${ }^{50}$ This results, however, is contrast with previous findings from the macro literature (e.g. Mauro 1995).
} 
that some (though not all) the rents transferred to firms in Albania and Kosovo are beneficial from the point of view of performance. Technical assistance programmes, in particular, both promote investment and allow firms to make more out of additional investments (although they may come with "strings attached", exacerbating the already rampant problem of overstaffing). The effectiveness of other common policy rents (e.g. political protection from domestic or foreign competitors) are more mixed. Even the growth premium from technical assistance, however, is unlikely to fully make up for the rent-seeking costs incurred by firms to secure the rents. Thus, on net, it would be more rational for Albanian and Kosovar firms not to make any "greasing" or rent-seeking expenditures. Future research should examine why it is the case that corruption persists if firms incur a net loss by engaging in it. A possible explanation is that our cross-section reflects a temporary departure from the equilibrium point. If so, the costs and benefits of corruption should balance out in the long-run.

Our findings contribute to the broader micro-literature on corruption and firm performance. In particular, they confirm and extend two closely related studies of transitional corruption. The first study is by Hellman et al. (2003), who suggest that "in the bargain between politicians and firms, the politician uses political power to provide rents to firms in return for private economic gains [i.e. bribes]" (p. 756). Based on data from 23 transition economies, they find that "influential" and "captor" firms - the firms that win out in rent-seeking contests - grow faster; overall bribe payments, however, have a negative impact on sales growth. The second study, based on a large sample of firms from 14 transition economies, is by Hanousek and Kochanova (2016). Although the mean frequency of bribery lowers the firm's rate of sales growth, the firms facing an environment with a high dispersion of bribery perform better. According to Hanousek and Kochanova (2016), this is because these firms are able to extract concentrated benefits (i.e. rents) from public officials.

Yet, neither of these two studies examines the mechanisms through which bribes and rents affect output growth, nor do they attempt to measure rents directly, as we do. By studying bribes and rents in a comprehensive framework, this paper contributes new perspectives to the literature on corruption and industrial policy. Because it relies on perception-based indicators, however, the usual caveats on interpreting the results causally apply.

Our findings also point towards important policy implications for Albania and Kosovo (and, by extension, other low-middle income transition economies). First, anti-corruption practitioners should distinguish the forms of corruption that are practiced to "grease the wheels" from those that involve the extraction of rents. These two forms of corruption call for very 
different responses. Consider the first form. Here, eliminating the corruption without solving the bottlenecks could in principle leave firms worse off (Khan et al. 2016). Yet, our findings suggest that, in Albania and Kosovo, the costs of "greasing the wheels" may exceed the costs imposed by the bottlenecks. If so, eliminating the corruption would in itself be beneficial. Nevertheless, a more comprehensive anti-corruption approach would target the bottlenecks themselves. Consider now the second form of corruption. Here, eliminating the rents in a bid to choke the corruption would amount to throwing the proverbial baby out with the bathwater, as the rents generated by industrial policies can help fledgling firms learn new technologies, accumulate productive capital, and become profitable and competitive more quickly.

Rather, and this is the second point, anti-corruption and economic policy practitioners should find ways to "formalise" industrial policy rents by decoupling them from bribery. Recent historical narratives have emphasised the important redistributive role played by rents in developing and transition economies: here, ruling elites create and distribute rents to appease powerful groups with violence potential and create political stability (North et al., 2012). These accounts have also emphasised that the first step towards the establishment of a more inclusive, rent-free social order is the creation of a "rule of law for elites" - a system where rents still exist but are no longer awarded to the highest bidder in a corrupt (rent-seeking) auction, but granted to promising or meritorious firms on technocratic grounds (ibid.).

Third, and lastly, donor agencies should consider scaling up projects that provide direct support to the private sector. Our results suggest that technical assistance programmes technology consulting, on-the-job training, marketing advice, etc. - are associated with higher rates of productivity growth, more investment, and higher returns from investment. These findings suggest that these programmes are indeed effective and should be considered preferable to loans and subsidies. More generally, donor agencies should consider carefully how rents, qua tools of political stabilisation, can be made compatible with the exigencies of economic growth. In Albania and Kosovo, these are just some of the issues that should become the focus of applied policy research in the future.

\section{APPENDIX A: Survey Design Characteristics}

The survey interviews were conducted face-to-face by nine native-speaking enumerators, who were trained by the authors. All enumerators were native speakers of Albanian, expect for one 
Kosovar enumerator, a native Serbian speaker, who was responsible for conducting interviews in the Serbian-majority municipalities of northern Kosovo. The respondent was always either the company's owner or a top manager. To ensure consistency and data quality, the authors supervised the firm-selection process and audited some 100 interviews across the two countries.

The survey employed adopted a two-stage sampling design. Using information from official business registries, the total population of industrial firms in Albania and Kosovo was first partitioned into 22 country-sectors, or "strata". Next, individual firms were selected independently within each stratum. Stratification ensures that firms from more successful sectors, which are naturally more numerous, are not overrepresented in the sample (Levy and Lemeshow 2008, p. 123).

Furthermore, the sampling procedure was such that larger firms (measured by the number of full-time employees) were more likely to be selected into the sample than smaller firms from the same stratum; firms of equal size were equally likely to be sampled. To implement this scheme, the stratum population was ranked by firm size. The interviewers were instructed to first telephone and arrange interviews with larger companies, working their way down in descending order. The randomness of selection arises from the possibility that a firm may not answer the phone call or may decline to be interviewed.

[Table A1]

Table A1 provides descriptive information on the 22 country-sectors, including the sample $\left(n_{h}\right)$ and population $\left(N_{h}\right)$ size for stratum $h$, the sampling rate $\left(f_{h}=n_{h} / N_{h}\right)$ and the share of the sample $\left(n_{h} / \sum n_{h}\right)$ and population $\left(N_{h} / \sum N_{h}\right)$ pertaining to each stratum.

\section{APPENDIX B: Factor Analysis of the Rent Dummies}

The factor analysis estimates the following system of equations, written in matrix form:

$$
\overrightarrow{R e n t}=\underline{A} \vec{f}+\vec{u}
$$

where $\overrightarrow{R e n t}$ is the vector of observed rent dummies, $\vec{f}$ is a vector of factor scores, $\underline{A}$ is the pattern matrix and $\vec{u}$ is the uniqueness vector. The elements $a_{m n}$ of the pattern matrix $(\underline{A})$ are known as "factor loadings", since they measure the partial correlation between each factor and the observed variables. Estimating $\underline{A}$ requires solving the following eigenvalue problem: $\underline{\Sigma} \vec{a}_{m i}=$ 
$\gamma_{i} \vec{a}_{m i}$, where $\underline{\Sigma}$ is the correlation matrix of the observed rent variables, $\vec{a}_{m i}$ is the vector of partial correlations between $f i$ and the four rent variables, and $\gamma_{i}$ is the eigenvalue.

A critical assumption of factor analysis is that the observed variables are continuous. Our Rent variables, however, are binary. A factor analysis of the Pearson correlation matrix for a set of dummies can be severely misleading. The standard solution is to factor-analyse the matrix of tetrachoric correlations between the observed dummies (StataCorp 2014, p. 2679). A tetrachoric correlation "estimates the Pearson correlation of the latent continuous variables" (ibid.). The assumption is that the respondents' agreement/disagreement with questions 1.1-1.4 is just a coarse measurement of an underlying variable - the degree to which firms in a given sector receive rents.

Having estimated the pattern matrix $\underline{A}$ using a principal-component method, we performed a rotation of the matrix elements, a standard procedure intended to simplify factor structure and aid interpretation of the factor scores (Hamilton 2013, p. 318). We employed an oblique promax rotation, which "simplifies factor patterns while permitting some degree of correlation between the factor [scores]. Correlated factors will be statistically less parsimonious [...], but [potentially] more realistic" (Hamilton 2013, p. 340). The results are very similar if we choose an orthogonal varimax rotation instead. We only retain factors whose eigenvalue is greater than 1, implying that they explain more than the equivalent of one observed variable's variance (Hamilton 2013, p. 316).

\section{APPENDIX C: Sampling Design and OLS Estimators}

Under our sampling scheme, a stratum is defined as the firm's country-sector. Each stratum $h$ consists of a finite population of firms $\left(N_{h}<\infty\right)$. To make a finite-population correction, we define the "sampling rate" $f_{h}$ for stratum $h$ as the ratio of sampled individuals to the size of the population in $h: f_{h}=n_{h} / N_{h}$.

Next, we weighted our observations by their probability of being selected into the sample. The "sampling weight" $w_{i h}$ for observation $i$ in stratum $h$ is proportional to the inverse of the probability of i's being selected into the sample. Under our sampling scheme, the probability of selection depends on the stratum's population size, but also on the size of the company, measured in terms of the number $L_{i}$ of full-time employees. Thus, following Levy and Lemeshow (2008, p. 350), we define the sampling weight as follows: 


$$
w_{i h}=\frac{C}{P_{i h}}=C\left(\frac{N_{h}}{n_{h}}\right)\left(\frac{1}{L_{i}}\right)
$$

where $P_{i h}$ is the probability of observation $i$ being selected and $C$ is a constant that we restrict to 1. To perform the estimation, we use Stata's svy suite of commands for survey data (Stata Corp. 2013).

\section{APPENDIX D: Output Growth Models: Additional Specifications}

Here, we further investigate the robustness of the results presented in column 4, Table 5 . In that model, the fact that the coefficients on $f 2,(f 2 \cdot \Delta \ln K)$ and $(f 2 \cdot \Delta \ln L)$ are all insignificant may result from multicollinearity. Thus, model 1 in Table A2 omits these two interaction terms $\mathrm{s}^{51}$, and recovers the positive and significant coefficient on $f 2$ estimated in models 2 and 3 (Table 5). Although the rents captured by $f 2$ (import protection and protection from unfair competition) do not exert a moderating influence on the marginal product of labour and capital, they do appear to stimulate TFP growth.

[Table A2]

Lastly, model 2 in Table A2 tests the robustness of our results to an alternative fixedeffects specification. The ability of firms to generate sales revenue may depend on sector- (e.g. prices) and/or location-specific (e.g. institutional) effects. Omitting these determinants of firm performance may bias the parameter estimates. For instance, an exogenous change in market prices may allow firms to increase revenues without improving product quality or increasing the scale of production; and this effect may be spuriously picked up by our rents or corruption variables. Alternatively, governance quality may vary across regions, and these differences may influence both the performance of local firms and the incidence of corruption (e.g. in the municipal bureaucracy). To address these possibilities, model 2 in Table A2 investigates the sensitivity of our results to replacing the country fixed-effect dummy (Albania) with a full set of country-sector and location (city) fixed effects. ${ }^{52}$ The location fixed-effects (but not the countrysector fixed-effects) enter as jointly significant. Even so, our results are qualitatively unaltered (although, of course, the OLS standard errors are generally much larger in this much more extensively specified model).

\footnotetext{
51 The $p$-value of a F-test of their joint significance is 0.902 .

${ }^{52}$ Interacting the sector FE with the Albania dummy allows for the sector-specific effects (due to technological characteristics, for instance) to vary between Albania and Kosovo.
} 


\section{REFERENCES}

Ades, A. and Di Tella R. 1997. National Champions and Corruption: Some Unpleasant Interventionist Arithmetic, Economic Journal, 107: 1023-42

Asiedu, E. and Freeman, J. 2009. The Effect of Corruption on Investment Growth: Evidence from Firms in Latin America, Sub-Saharan Africa, and Transition Countries. Review of Development Economics 13(2): 200-14

Athanasouli, D., Goujard 2015. Corruption and Management Practices: Firm Level Evidence, Journal of Comparative Economics 43(4): 1014-1034

Azfar, O. and Murrell, P. 2009. Identifying reticent respondents: Assessing the quality of survey data on corruption and values. Economic Development and Cultural Change 57(2): 387-411

Bartlett, W. 2008. Europe's Troubled Region: Economic Development, Institutional Reform and Social Welfare in the Western Balkans. Routledge: London and New York

Beltràn, A. 2016. Does Corruption Increase or Decrease Employment in Firms?, Applied Economics Letters, 23(5): 361-364

Capussela, A. L. 2015. State-Building in Kosovo: Democracy, Corruption and the EU in the Balkans. I.B. Tauris

Chang, H.-J. 2002. Kicking away the Ladder: Development Strategy in Historical Perspective. Anthem Press

Clarke, G.R.G., Friesenbichler, K.S. and Wong M. 2015. Do Indirect Questions Reduce Lying about Corruption? Evidence from a Quasi-Field Experiment, Comparative Economic Studies 57: 103135

Commander, S. and Svejnar J. 2011. Business Environment, Exports, Ownership and Firm Performance, Review of Economics and Statistics, 93(1): 309-337

Dal Bo, E. and Rossi M. 2007: Corruption and Inefficiency: Theory and Evidence from Electric Utilities, Journal of Public Economics, 91(5): 939-962

Danielsson, A. 2016. Reforming and Performing the Informal Economy: Constitutive Effects of the World Bank's Anti-Informality Practices in Kosovo. Journal of Intervention and Statebuilding 10(2): 241-260

Douarin, E. and T. Mickiewicz. 2017. Economics of Institutional Change: Central and Eastern Europe Revisited. Cham: Palgrave MacMillan

Estrin, S. and Uvalic M. 2016. Foreign Direct Investment in the Western Balkans: What Role Has it Played During Transition Comparative Economic Studies, 58(3): 455-483

Fisman, R., Svensson, J. 2007. Are Corruption and Taxation really Harmful to Growth? Firm Level Evidence. Journal of Development Economics 83(1): 63-75

Friedman, E., Johnson, S., Kaufmann, D., Zoido-Lobaton, P. 2000. Dodging the Grabbing Hand: The Determinants of Unofficial Activity in 69 Countries, Journal of Public Economics, 76: 459493

Frydman, R., Gray, C., Hessel, M. Rapaczynski, A. 1999. When Does Privatisation Work? The Impact of Private Ownership on Corporate Performance in The Transition Economies. Quarterly Journal of Economics 114 (4): 1153-1191

Gatti, R. and I. Love 2008. Does access to credit improve productivity? Evidence from Bulgaria. Economics of Transition 16(3): 445-465

Hamilton, L.C. 2013. Statistics with Stata: Updated for Version 12, 8th ed. Boston, MA: Brooks/Cole 
Hanousek, J. and A. Kochanova. 2016. Bribery Environments and Firm Performance: Evidence from CEE countries. European Journal of Political Economy 43: 14-28

Heckelman, J.C. and Powell, B. 2010. Corruption and the Institutional Environment for Growth, Comparative Economic Studies, 52: 351-378

Hellman, J. S., Jones, G., Kaufmann, D. 2003. Seize the State, Seize the Day: State Capture and Influence in Transition Economies. Journal of Comparative Economics 31(4): 751-773

Khan, M.H. 2000. Rent-seeking as Process, in M.H. Khan and K.S. Jomo (eds) Rents, Rent-Seeking and Economic Development, pp. 70-144. Cambridge: Cambridge University Press.

Khan, M.H. 2001. The New Political Economy of Corruption, in B. Fine, C. Lapavitsas and J. Pincus (eds) Development Policy in the Twenty-First Century: Beyond the Post-Washington Consensus, pp. 112-35. New York: Routledge.

Khan, M.H., Andreoni, A, Roy, P. 2016. Anti-Corruption in Adverse Contexts: A Strategic Approach, mimeo. London: School of Oriental and African Studies

Leff, N. 1964. Economic Development Through Bureaucratic Corruption. American Behavioural Scientist 8(3): 8-14

Lemay-Hebert, N. and Mansoob Murshed, S. 2016. Rentier State-Building in a Post-conflict Economy: The Case of Kosovo. Development and Change 47(3): 517-41

Levy, P. S., Lemeshow, S. 2008. Sampling of Populations: Methods and Applications, Fourth Edition, Hoboken, NJ: Wiley

Lui, F. 1985. An Equilibrium Queuing Model of Bribery. Journal of Political Economy 93(4):

Mauro, P. 1995. Corruption and Growth. Quarterly Journal of Economics 110(3): 681-712

Meon, P.-G., Weill, L. 2010. Is Corruption and Efficient Grease? World Development 38(3): 244-59

MTI 2015. Annual Report \#1 - 15 Years of Transition in Kosovo: Implications for Trade. Ministry of Trade and Industry, EU Trade Policy Project: Prishtine

North, D. C., Wallis, J.J., Webb, S.B. and Weingast, B.R. 2009. (eds) 2012. In the Shadow of Violence: Politics, Economics and the Problems of Development. Cambridge: Cambridge University Press.

Olken, B. 2009. Corruption Perceptions vs. Corruption Reality. Journal of Public Economics 93: 950-64

RoK 2016. National Development Strategy, 2016-2021. Office of the Prime Minister, Republic of Kosovo, Prishtine

Seker, M. and Yang, J. 2014. Bribery Solicitations and Firm Performance in the Latin America and Caribbean region. Journal of Comparative Economics 42: 246-264

StataCorp. 2013. Stata Survey Data Reference Manual: Release 13. College Station, TX: Stata Press.

StataCorp. 2014. Stata Base Reference Manual: Release 14. College Station, TX: Stata Press

Szirmai, A. 2012. Industrialisation as an Engine of Growth in Developing Countries, 1950-2005. Structural Change and Economic Dynamics 23(4): 406-20

Szirmai, A. and B. Verspagen. 2015. Manufacturing and Economic Growth in Developing Countries, 1950-2005. Structural Change and Economic Dynamics 34: 46-59

Tybout, J. 2003. Plant and Firm-Level Evidence on the "New" Trade Theories, in E. Kwan Choi and J. Harrigan (eds) Handbook of International Trade. Oxford: Basil Blackwell

Uberti, L. J. 2014. Neoliberalism and Industrial Policy in Kosovo: The Mining and Metals Industry in the Post-War Transition. East European Politics 30, 482-506

Uberti, L.J. 2016. The "Sociological Turn" in Corruption Studies. Progress in Development Studies 16(3): 261-77 
Uberti, L. J. 2017. Good Governance, Corruption and Growth: A Political Economy of PostSocialist Industrial Transformation in Albania and Kosovo, 1998-2015, PhD thesis, University of Otago

Uberti, L.J. 2019. Economy (Kosovo), in I. Gladman (ed) Central and South-Eastern Europe 2020, 20th edition, pp. 315-319. Abingdon: Routledge

UNDP. 2012. Kosovo Human Development Report 2012: Private Sector and Employment.

Prishtina: United Nations Development Programme

UNDP. 2016. Human Development Report Albania 2016: Functionality. Tirana: United Nations Development Programme

Wetzstein, M. 2004. Microeconomic Theory: Concepts and Connections. 1st Edition, Cengage Learning

World Bank. 2010. Kosovo - Unlocking Growth Potential: Strategies, Policies, Actions. A Country Economic Memorandum, Report No. 53185-XK, April 29.

World Bank. 2017. Country Partnership Framework for Republic of Kosovo for the Period FY17FY21, Report No. 112337-XK, The World Bank Group 